\title{
Preliminary safety and imaging efficacy of the near-infrared fluorescent contrast agent DA364 during fluorescence-guided surgery in dogs with spontaneous superficial tumors
}

\author{
Sophie Favril ${ }^{1,2, *}$, Chiara Brioschi ${ }^{3, *}$, Katrien Vanderperren ${ }^{4}$, Eline Abma ${ }^{1,2}$, Emmelie \\ Stock ${ }^{4}$, Nausikaa Devriendt ${ }^{1}$, Ingeborgh Polis ${ }^{1}$, Hilde De Cock ${ }^{5}$, Alessia Cordaro ${ }^{3}$, \\ Luigi Miragoli ${ }^{3}$, Paolo Oliva ${ }^{3}$, Giovanni Valbusa ${ }^{6}$, Charline Alleaume ${ }^{7}$, Isabelle Tardy ${ }^{7}$, \\ Alessandro Maiocchi ${ }^{3}$, Fabio Tedoldi ${ }^{3}$, Francesco Blasi ${ }^{3, *}$ and Hilde de Rooster ${ }^{1,2, *}$ \\ ${ }^{1}$ Small Animal Department, Faculty of Veterinary Medicine, Ghent University, Merelbeke, Belgium \\ ${ }^{2}$ Cancer Research Institute Ghent, Ghent, Belgium \\ ${ }^{3}$ Bracco Imaging SpA, c/o BioIndustry Park, Colleretto Giacosa, Italy \\ ${ }^{4}$ Department of Veterinary Medical Imaging and Small Animal Orthopaedics, Faculty of Veterinary Medicine, Ghent University, \\ Merelbeke, Belgium \\ ${ }^{5}$ Medvet/Algemeen Medisch Laboratorium, Antwerpen, Belgium \\ ${ }^{6}$ Ephoran Multi-Imaging Solutions, Colleretto Giacosa, Italy \\ ${ }^{7}$ Bracco Suisse S.A., Plan-les-Ouates, Switzerland \\ *These authors contributed equally to this work \\ Correspondence to: Favril Sophie, email: Sophie.Favril@ugent.be \\ Keywords: fluorescence-guided surgery; fluorescent contrast agent; near-infrared fluorescence imaging; spontaneous tumors; \\ canine \\ Received: January 08, $2020 \quad$ Accepted: May 14, $2020 \quad$ Published: June 16, 2020 \\ Copyright: Sophie et al. This is an open-access article distributed under the terms of the Creative Commons Attribution License \\ 3.0 (CC BY 3.0), which permits unrestricted use, distribution, and reproduction in any medium, provided the original author and \\ source are credited.
}

\section{ABSTRACT}

Tumor-targeting contrast agents may facilitate resection of solid neoplasms during fluorescence-guided surgery. Preliminary safety and imaging efficacy of the near-infrared fluorescent probe DA364 were evaluated during surgical resection of spontaneous solid tumors in $\mathbf{2 4}$ dogs. Intra-operative imaging was performed in situ and on excised specimens to evaluate fluorescence intensities of tumor and adjacent tissues. After standard-of-care tumor resection, the wound bed was imaged again, and additional tissue was excised if residual fluorescence was detected.

DA364 was well tolerated after intravenous administration. The median tumorto-background ratio in situ for mammary tumors, mast cell tumors and sarcomas was 1.8 (range 1.2-3.9), 2.2 (range 1.0-5.6), and 4.2 (range 2.0-4.3), respectively. Qualitative intra-operative tumor identification was feasible in half of the cases. Remaining fluorescence was detected in four wound beds that contained residual disease, and in 11 tumor-free wound beds, confirmed by histopathology.

Overall, DA364 did not raise safety concerns and showed accumulation in different types of spontaneous tumors, showing potential to pinpoint residual disease. Larger clinical trials are necessary to select accurate dosing and imaging protocols for specific indications to evaluate the sensitivity and specificity of the agent. 


\section{INTRODUCTION}

Despite many recent improvements in the medical treatment of cancer, surgery remains the most effective therapeutic strategy for the majority of patients with solid tumors [1]. Tissue palpation, visual inspection, and real-time frozen section analyses are commonly used by surgeons to identify tumor margins during resection, and to assess the presence of residual disease [1]. However, positive tumor margins after surgical resection are a common histopathological finding [2-4], which strongly increases the risk of cancer recurrence [5]. Thus, there is a high need for the implementation of new intra-operative methodologies that can provide accurate real-time tumor margin assessment to overcome the limitations of standard-of-care practice.

Fluorescence imaging is a safe and sensitive technique that may assist the surgeon by real-time delineation of tumor lesions during resection through visualization of specific fluorescent probes [6-8]. Particularly intra-operative near-infrared fluorescence (NIRF; 700-900 nm) imaging is currently being investigated using contrast agents that preferentially accumulate in tumor tissues, and that may be detected at greater depths and with higher image resolution than tracers emitting in the visible spectrum [8]. Indocyanine Green (ICG), the only NIRF agent currently approved for human use (i.e., angiography, lymph node (LN) mapping, liver function testing), has demonstrated limited sensitivity and specificity for intra-operative tumor identification in human and veterinary trials [9-11], due to its unspecific tumor accumulation mechanism. Novel contrast agents that recognize molecular epitopes overexpressed by tumor tissues (i.e., vascular endothelial growth factor, folate receptor, carcinoembryonic antigen) have shown safety and efficacy during clinical trials and hold great promise to be implemented in clinical practice [12-16].

In this study, preliminary safety and imaging efficacy of the NIRF agent DA364 were evaluated during resection of superficial solid tumors in canine patients. DA364 is composed of Cy5.5, a water-soluble cyanine dye (fluorescence quantum yield in serum: Cy5.5, 21\%; ICG, 9\%) [17, 18], and a cyclic Arg-Gly-Asp (RGD) peptidomimetic moiety, targeting integrins, which are the main cellular adhesion protein family implicated in nearly every step of tumor progression $[19,20]$. It has previously been reported that DA364 has high affinity and specificity for integrin $\alpha_{\mathrm{v}} \beta_{3}$ in vitro, and excellent imaging performance in vivo to detect tumor masses in rodent models of human cancers [21, 22]. In vitro evaluations were conducted to test the biological properties of the DA364 batch used for the canine trial. Based on the promising pre-clinical results, we hypothesize that DA364 accumulates in spontaneous tumors in dogs after intravenous (IV) administration, allowing intra-operative tumor detection and eradication of residual disease in the wound bed. Secondary objectives of the trial are: 1) to evaluate the probe's tissue kinetics after injection, 2) to determine the optimal dose and time interval for tumor detection during surgery, and 3 ) to assess the pattern of integrin receptor expression in different tissues.

\section{RESULTS}

\section{In vitro analyses}

DA364 affinity to human $\alpha_{v} \beta_{3}$ integrin was evaluated in a solid phase binding assay via displacement of vitronectin, the physiological ligand of the receptor (Figure 1A). DA364 was able to compete for the binding to the target with single-digit nanomolar potency $\left(\mathrm{IC}_{50}\right.$ $2.5 \pm 0.2 \mathrm{nM}$ ), confirming the findings from previous batches of the product [21].

DA364 showed efficient internalization in human melanoma WM266 cells which overexpress the integrin receptor $\alpha_{v} \beta_{3}$ [23] (Figure 1B). The treatment with the competitor inhibited DA364 internalization in a dosedependent manner. An uptake inhibition of $85 \%$ was reached with a 50 -fold concentration of the unconjugated cRGD peptidomimetic moiety.

\section{Patient characteristics and study workflow}

Between February 2016 and April 2017, 24 dogs with 32 suspected superficial solid tumors were included in the clinical trial. Table 1 illustrates the general characteristics of the dogs, the tumor type (s) and respective trial data. The histopathological diagnosis of the major tumors revealed the presence of mast cell tumor $(n=9)$, mammary gland adenocarcinoma $(n=6)$, mammary gland adenoma $(n=2)$, vaginal leiomyosarcoma $(n=1)$, soft tissue sarcoma $(n=1)$, osteosarcoma $(n=1)$, cutaneous melanoma $(n=1)$, adenocarcinoma of the apocrine gland $(n=1)$, cysts of the mammary gland $(n=1)$, and lipoma $(n=1)$. Histopathological diagnosis of second smaller tumors that were identified during physical examination in eight dogs revealed the presence of an additional mammary gland adenoma $(n=5)$, mammary gland adenocarcinoma $(n=2)$, and pyogranulomatous dermatitis $(n=1)$. The cysts of the mammary gland and the pyogranulomatous dermatitis lesion were not included in any further analyses since both lesions do not have a neoplastic origin.

The study workflow (Figure 2) started with the IV administration of DA364 at various doses either 24 or $48 \mathrm{~h}$ prior to surgery, followed by pre-operative imaging to assess tissue kinetics, then intra-operative imaging to evaluate fluorescence in tumors and surroundings, and post-operative imaging of resected specimen to verify the distribution of the fluorescent signal. Furthermore, the excised specimens were prepared for histopathological 
assessment and for proteomic analyses to evaluate the expression of the integrin receptors.

\section{Pre-operative imaging}

No adverse effects were observed after IV administration of DA364. All patients were clinically stable; heart rate, respiratory rate and systolic blood pressure were within physiological ranges throughout the experiment. Reliable pre-operative kinetics were obtained in 12 tumors $(5 \mathrm{a}, 6,7,9,11,14,17,18,19 \mathrm{a}, 20 \mathrm{a}, 23$, 24). The selection of sufficient transcutaneous images of tumors was based on optimal image quality, which was highly affected by parameters such as the thickness and color of the skin, and transcutaneous fluorescence imaging feasibility, which was affected by the location of tumor. Analysis of the signal decay over time revealed a peak $\left(\mathrm{T}_{\max }\right)$ at $1.6 \mathrm{~h}$ post-injection (PI) and long-lasting tissue retention in the tumors $\left(\mathrm{T}_{1 / 2}: 16.5 \mathrm{~h}\right)$.

\section{Intra-operative imaging}

The tumor was always removed with a certain margin of surrounding tissue, depending on the current recommendations for each tumor type, meaning no attempt was done to resect the tumor based on the intensity of the fluorescent signal. The dose of $0.06 \mathrm{mg} / \mathrm{m}^{2}$ was too low for intra-operative NIRF tumor detection. The dose of 0.6 $\mathrm{mg} / \mathrm{m}^{2}$ was sufficient to detect the tumor in situ, but the dose of $1.8 \mathrm{mg} / \mathrm{m}^{2}$ revealed sharper images, and therefore was selected as primary dose for the trial (Table 1). The dose of $3 \mathrm{mg} / \mathrm{m}^{2}$ did not improve image quality compared to the $1.8 \mathrm{mg} / \mathrm{m}^{2}$ dose whereas increased background fluorescence was observed.

The median tumor-to-background ratio (TBR) in situ for all mammary tumors, mast cell tumors and sarcomas was 1.8 (range 1.2-3.9), 2.2 (range 1.0-5.6), and 4.2 (range 2.0-4.3), respectively (Table 2, Figure 3 ).

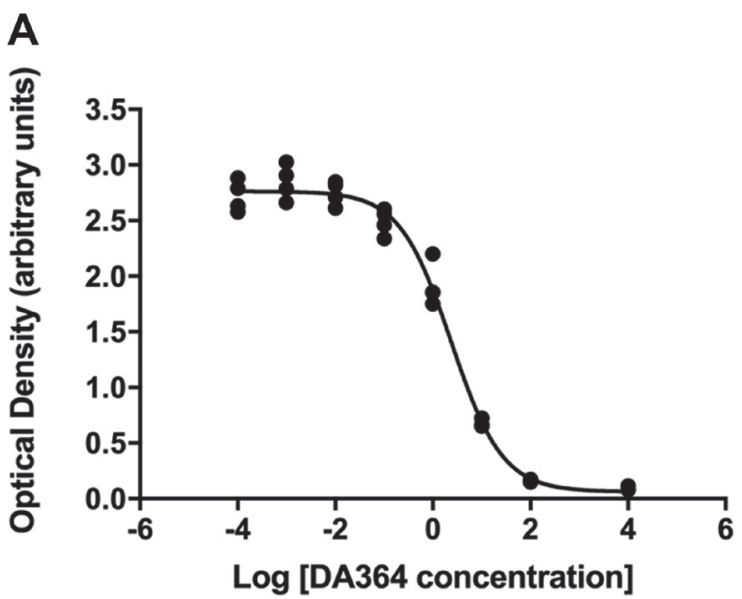

The analysis was not performed on six mammary tumors (two of which were adenocarcinomas) because the image quality was suboptimal, either due to the low dose of contrast administered or due to a tumor diameter of less than $5 \mathrm{~mm}$. Although the intra-operative TBR was $\geq 1.0$ in all tumors (with the exception of the highly pigmented melanoma), the intra-operative qualitative evaluation showed a distinctive positive signal of the exposed lesion compared to adjacent tissues in only 15 out of 30 tumors (Table 2). The lowest TBR in the tumor that was qualitatively identified was 1.2. Furthermore, there was no significant difference in TBRs between malignant tumors and benign lesions. Malignant mammary gland tumor patients imaged $48 \mathrm{~h}$ after administration showed subjectively lower background fluorescence than patients imaged after $24 \mathrm{~h}$. However, delaying the surgery and acquisition to $48 \mathrm{~h}$ PI did not result in appreciable improvement of the in vivo TBR.

Complete resection of the tumor was deemed successful by standard-of-care evaluation in 27 out of 30 lumps, and histopathology claimed negative surgical margins in 26 of those (Table 3). In two mast cell tumor cases (patients 11 and 22) and in the melanoma (patient 16), complete resection was not feasible due to the location (proximity of the eye and tarsus). As expected, tumor margins contained microscopic tumor remnants and fluorescence was detected in the wound bed (true positives). In one mast cell tumor (patient 10), a fluorescence signal was detected in the surgical bed, and histopathology showed that the tumor tissue reached until the section margins (true positive, undetected during surgery by standard-of-care examination). No remaining fluorescence was noted in 15 of the 26 histopathologicallyclean wound beds (true negatives, mostly mammary gland tumors). In the 11 remaining wound beds, fluorescence was noted but the biopsies did not contain tumor cells (false positives, mostly mast cell tumors and sarcomas) (Table 3).

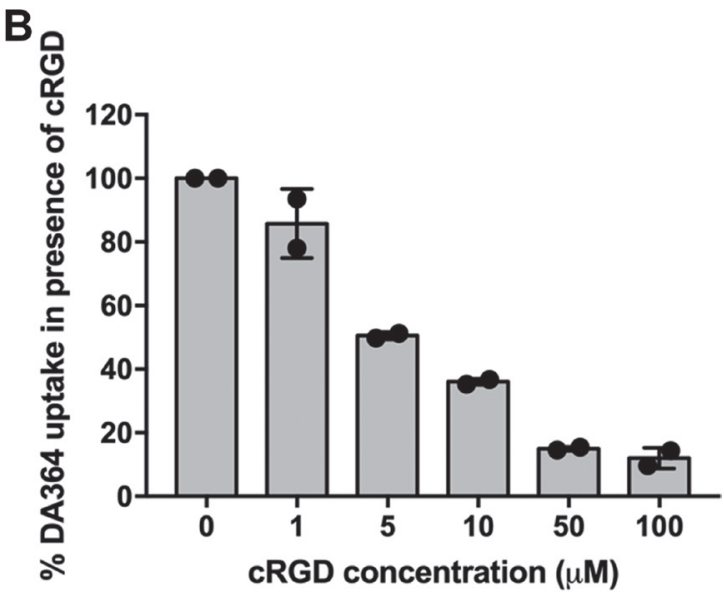

Figure 1: In vitro analyses. (A) Representative sigmoid curve revealing single-digit nanomolar affinity of DA364 for the human $\alpha_{\mathrm{v}} \beta_{3}$ integrin receptor. (B) Dose-response inhibition of DA364 uptake in human melanoma WM266 cells by the unconjugated cRGD vector. 
Table 1: General patient and tumor characteristics and respective trial data of dogs enrolled for fluorescence imaging

\begin{tabular}{|c|c|c|c|c|c|c|c|c|c|c|}
\hline Dog & $\begin{array}{l}\text { TI } \\
\text { (h) }\end{array}$ & $\begin{array}{c}\text { Dose } \\
\left(\mathrm{mg} / \mathrm{m}^{2}\right)\end{array}$ & Breed (gender) & $\begin{array}{l}\text { Age } \\
(y)\end{array}$ & $\begin{array}{l}\text { Weight } \\
\text { (kg) }\end{array}$ & $\begin{array}{c}\text { BCS } \\
{[31]}\end{array}$ & Tumor/le & esion charac & teristic & \\
\hline & & & & & & & Type & Stage [32] & Grade & Site \\
\hline 1 & 24 & 0.06 & $\begin{array}{l}\text { American } \\
\text { Staffordshire } \\
\text { Terrier }(\mathrm{F})\end{array}$ & 6.7 & 27.0 & 4 & $\begin{array}{l}\text { 1a: Adenoma } \\
\text { 1b: Adenoma }\end{array}$ & $\begin{array}{l}\text { T1N0M0 } \\
\text { T1N0M0 }\end{array}$ & - & $\begin{array}{l}\text { Mammary } \\
\text { gland }\end{array}$ \\
\hline 2 & 24 & 0.6 & $\begin{array}{l}\text { Jack Russell } \\
\text { Terrier (Fn) }\end{array}$ & 12.3 & 4.5 & 4 & $\begin{array}{l}\text { 2a: Adenocarcinoma } \\
\text { 2b: Adenocarcinoma }\end{array}$ & $\begin{array}{l}\text { T2N1M0 } \\
\text { T1N0M0 }\end{array}$ & $\begin{array}{c}\text { III } \\
\text { I }\end{array}$ & $\begin{array}{l}\text { Mammary } \\
\text { gland }\end{array}$ \\
\hline 3 & 24 & 1.8 & Weimaraner (F) & 6.3 & 40.0 & 6 & Cysts & - & - & $\begin{array}{l}\text { Mammary } \\
\text { gland }\end{array}$ \\
\hline 4 & 24 & 1.8 & Malinois (Fn) & 14.0 & 27.0 & 4 & $\begin{array}{l}\text { 4a: Adenocarcinoma } \\
\text { 4b: Adenoma }\end{array}$ & $\begin{array}{l}\text { T3N1M0 } \\
\text { T1N0M0 }\end{array}$ & $\begin{array}{l}\text { III } \\
-\end{array}$ & $\begin{array}{l}\text { Mammary } \\
\text { gland }\end{array}$ \\
\hline 5 & 24 & 1.8 & $\begin{array}{l}\text { Yorkshire } \\
\text { Terrier }(\mathrm{F})\end{array}$ & 13.9 & 3.5 & 3 & $\begin{array}{l}\text { 5a: Leiomyosarcoma } \\
\text { 5b: Adenoma }\end{array}$ & $\begin{array}{l}\text { T3N0M0 } \\
\text { T1N0M0 }\end{array}$ & - & $\begin{array}{l}\text { Vagina } \\
\text { Mammary } \\
\text { gland }\end{array}$ \\
\hline 6 & 24 & 1.8 & $\begin{array}{l}\text { American } \\
\text { Staffordshire } \\
\text { Terrier (Fn) }\end{array}$ & 10.0 & 23.0 & 4 & Mast cell tumor & Ia & I & Mid-femur \\
\hline 7 & 24 & 1.8 & $\begin{array}{l}\text { Labrador } \\
\text { retriever (Fn) }\end{array}$ & 8.2 & 34.5 & 5 & Mast cell tumor & Ia & II & $\begin{array}{l}\text { Ventral } \\
\text { abdomen }\end{array}$ \\
\hline 8 & 24 & 1.8 & $\begin{array}{l}\text { Cross breed } \\
\text { (M) }\end{array}$ & 12.9 & 5.5 & 4 & Mast cell tumor & Ia & II & $\begin{array}{l}\text { Ventral } \\
\text { abdomen }\end{array}$ \\
\hline 9 & 24 & 1.8 & Maltese (Mn) & 8.1 & 8.5 & 4 & Mast cell tumor & Ia & II & Left femur \\
\hline 10 & 24 & 1.8 & $\begin{array}{l}\text { Jack Russell } \\
\text { Terrier (F) }\end{array}$ & 5.7 & 8.5 & 6 & Mast cell tumor & $\mathrm{IIb}$ & III & $\begin{array}{l}\text { Left thoracic } \\
\text { wall }\end{array}$ \\
\hline 11 & 24 & 1.8 & $\begin{array}{l}\text { Labrador } \\
\text { retriever }(\mathrm{F})\end{array}$ & 7.5 & 31.5 & 5 & Mast cell tumor & Ia & II & Tarsal region \\
\hline 12 & 24 & 3.0 & Maltese (F) & 6.3 & 6.5 & 4 & Adenoma & T1N0M0 & - & $\begin{array}{l}\text { Mammary } \\
\text { gland }\end{array}$ \\
\hline 13 & 24 & 3.0 & Cross breed $(\mathrm{F})$ & 9.3 & 12.0 & 4 & $\begin{array}{l}\text { 13a: SCC/ } \\
\text { Adenocarcinoma } \\
\text { 13b: Adenoma }\end{array}$ & $\begin{array}{l}\text { T2N0M0 } \\
\text { T1N0M0 }\end{array}$ & $\mathrm{I}$ & $\begin{array}{l}\text { Mammary } \\
\text { gland }\end{array}$ \\
\hline 14 & 24 & 1.8 & $\begin{array}{l}\text { German } \\
\text { shepherd (Mn) }\end{array}$ & 3.9 & 40.0 & 5 & Soft tissue sarcoma & T3N0M0 & II & Elbow region \\
\hline 15 & 24 & 1.8 & $\begin{array}{l}\text { Dobermann } \\
(\mathrm{Mn})\end{array}$ & 1.7 & 39.0 & 4 & Osteosarcoma & T2N0M0 & - & $\begin{array}{l}\text { Left thoracic } \\
\text { wall }\end{array}$ \\
\hline 16 & 24 & 1.8 & Shar-Pei (M) & 12.4 & 24.0 & 5 & Melanoma & T2N0M0 & $\begin{array}{l}\text { High } \\
\text { grade }\end{array}$ & Left cheeck \\
\hline 17 & 24 & 1.8 & $\begin{array}{l}\text { Border Collie } \\
(\mathrm{M})\end{array}$ & 10.3 & 26.0 & 6 & Adenocarcinoma & T3N0M0 & - & $\begin{array}{l}\text { Apocrine } \\
\text { glands } \\
\text { surrounding } \\
\text { the left anal } \\
\text { sac }\end{array}$ \\
\hline 18 & 24 & 1.8 & $\begin{array}{l}\text { Labrador } \\
\text { retriever (Fn) }\end{array}$ & 9.5 & 41.0 & 6 & Lipoma & - & - & $\begin{array}{l}\text { Right } \\
\text { inguinal area }\end{array}$ \\
\hline 19 & 48 & 1.8 & $\begin{array}{l}\text { Miniature } \\
\text { Poodle (F) }\end{array}$ & 8.4 & 4.0 & 4 & $\begin{array}{l}\text { 19a: Adenocarcinoma } \\
\text { 19b: Adenoma }\end{array}$ & $\begin{array}{l}\text { T1N0M0 } \\
\text { T1N0M0 }\end{array}$ & $\begin{array}{l}\text { I } \\
-\end{array}$ & $\begin{array}{l}\text { Mammary } \\
\text { gland }\end{array}$ \\
\hline
\end{tabular}




\begin{tabular}{|c|c|c|c|c|c|c|c|c|c|c|}
\hline 20 & 48 & 1.8 & $\begin{array}{l}\text { Jack Russell } \\
\text { Terrier (F) }\end{array}$ & 12.8 & 7.0 & 5 & $\begin{array}{l}\text { 20a: Adenocarcinoma } \\
\text { 20b: Adenocarcinoma }\end{array}$ & $\begin{array}{l}\text { T1N0M0 } \\
\text { T1N0M0 }\end{array}$ & $\begin{array}{l}\text { I } \\
\text { I }\end{array}$ & $\begin{array}{l}\text { Mammary } \\
\text { gland }\end{array}$ \\
\hline 21 & 48 & 1.8 & $\begin{array}{l}\text { Labrador } \\
\text { retriever }(\mathrm{F})\end{array}$ & 9.9 & 37.0 & 5 & Adenocarcinoma & T2N0M0 & I & $\begin{array}{l}\text { Mammary } \\
\text { gland }\end{array}$ \\
\hline 22 & 48 & 1.8 & $\begin{array}{l}\text { Labrador } \\
\text { retriever (M) }\end{array}$ & 11.1 & 41.0 & 6 & $\begin{array}{l}\text { 22a: Mast cell tumor } \\
\text { 22b: PGD }\end{array}$ & $\begin{array}{l}\text { Ia } \\
-\end{array}$ & $\begin{array}{l}\text { III } \\
-\end{array}$ & Right tarsus \\
\hline 23 & 48 & 1.8 & $\begin{array}{l}\text { Weimaraner } \\
(\mathrm{Mn})\end{array}$ & 6.1 & 39.0 & 6 & Mast cell tumor & Ia & II & Left stifle \\
\hline 24 & 48 & 1.8 & $\begin{array}{l}\text { American } \\
\text { Staffordshire } \\
\text { Terrier (Mn) }\end{array}$ & 10.3 & 35.0 & 5 & Mast cell tumor & IIa & III & Right tarsus \\
\hline
\end{tabular}

Abbreviations: BCS, body condition score; F, female; Fn, female neutered; M, male; Mn, male neutered; PGD, pyogranulomatous dermatitis; SCC, squamous cell carcinoma; TI, time interval.

\section{Post-operative imaging}

The fluorescence intensity in the center (tumor) and the outer edge (surgical margin) of the excised lumps was evaluated before formalin fixation (Figure 4). Eight samples were not included due to suboptimal image quality (Table 2). The median tumor-to-margin ratio (TMR) for all benign tumors and malignant tumors (melanoma not included) was 2.4 (range 1.6-3.4) and 3.4 (range 1.2-14.4), respectively. Although subjectively a higher TMR was noticed in malignant tumors compared to benign lesions, statistical significance was not reached $(p=0.203)$. The median TMR ex vivo for all mammary tumors, mast cell tumors and sarcomas was 3.4 (range 1.6-6.4), 2.6 (range 2.0-12.2), and 3.3 (range 1.2-5.4) respectively.
The signal-to-background ratio (SBR) in metastatic lymph nodes $(3.28 \pm 0.37)$ was significantly higher than in normal lymph nodes $(1.58 \pm 0.12)(\mathrm{t}(4.83)=-4.32$; $p=0.008$ ) (Table 4). Qualitative evaluation of the excised LNs revealed a positive signal in all metastatic LN, while only two non-metastatic LNs showed detectable fluorescence.

\section{Western blot and immunohistochemistry}

The expression of the integrin subunits $\alpha_{\mathrm{v}}$ and $\beta_{3}$ in canine tumor extracts was not homogenous within the groups, and no relationship was found between integrin expression levels and tumor type, location or grade (Figure 5A). The expression of the $\alpha_{\mathrm{V}}$ subunit appeared greater than the $\beta_{3}$ subunit in mammary gland tumors and

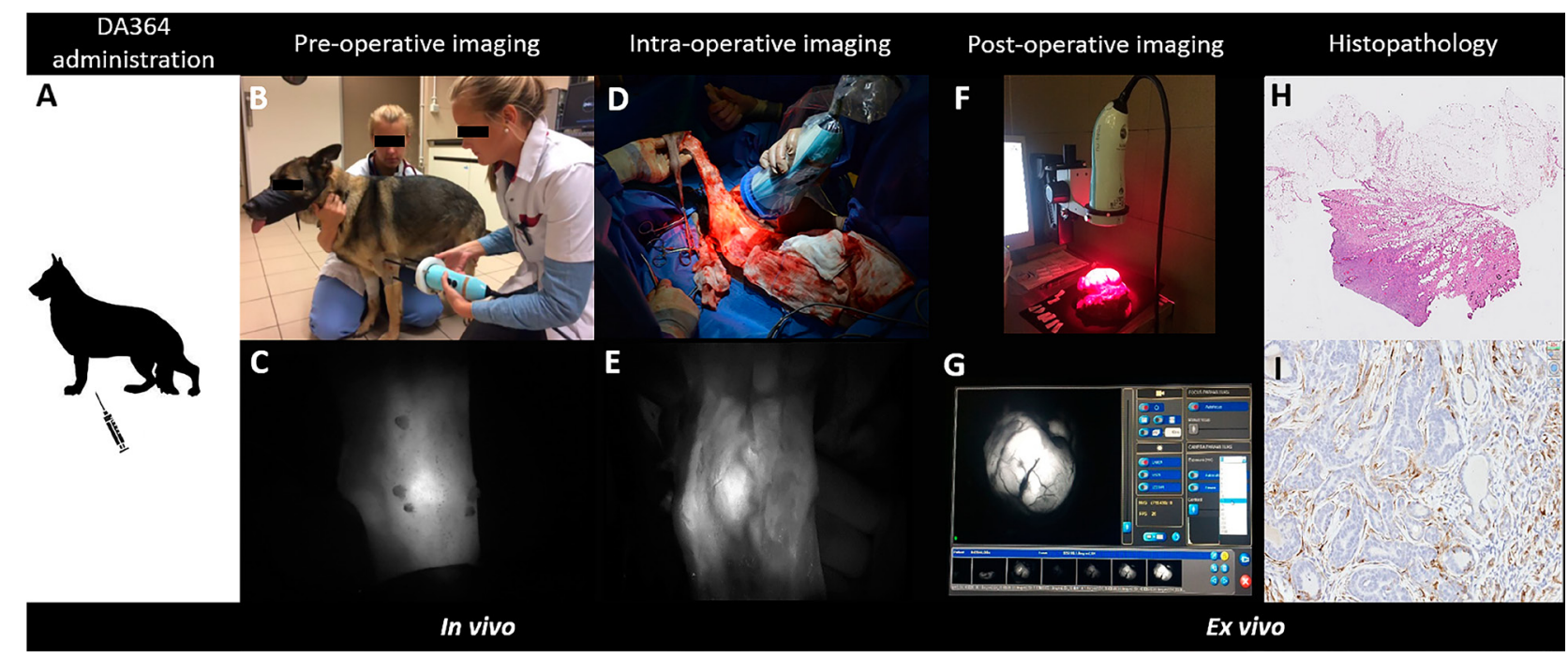

Figure 2: Overview of the procedure to test DA364 as fluorescent contrast agent to highlight tumors during surgery. The workflow consists of the intravenous administration of DA364 $24 \mathrm{~h}$ or $48 \mathrm{~h}$ prior to surgery (A), followed by pre-operative imaging (B, C: procedure and fluorescent image in panel respectively), intra-operative imaging (D, E: procedure and correspondent fluorescent image in panel respectively) and post-operative imaging (F, G: procedure and correspondent fluorescent image, visualized on screen, respectively). Excised tissues were sliced in $4 \mu \mathrm{m}$-thick sections and underwent tumor assessment by Hematoxylin and Eosin histopathology $(\mathbf{H})$, and evaluation of the $\beta_{3}$ integrin by immunohistochemistry (I). 
Table 2: Evaluation of fluorescence intensity in situ and on excised specimens

\begin{tabular}{|c|c|c|c|c|c|c|c|c|c|}
\hline \multirow[t]{2}{*}{ Dog } & \multirow[t]{2}{*}{ Tumor type } & \multirow[t]{2}{*}{$\begin{array}{c}\begin{array}{c}\text { Dose } \\
\left(\mathrm{mg} / \mathrm{m}^{2}\right)\end{array} \\
\end{array}$} & \multicolumn{4}{|c|}{ Intra-operative (in vivo) } & \multicolumn{3}{|c|}{ Post-operative (ex vivo) } \\
\hline & & & Lesion & Background & $T B R$ & $\begin{array}{l}\text { Qualitative } \\
\text { evaluation }^{a}\end{array}$ & Center & Margin & $T M R$ \\
\hline \multirow[t]{2}{*}{1} & 1a: Adenoma & 0.06 & $\mathrm{NA}^{\mathrm{b}}$ & $\mathrm{NA}^{\mathrm{b}}$ & $\mathbf{N A}^{\mathrm{b}}$ & - & $\mathrm{NA}^{\mathrm{b}}$ & $\mathrm{NA}^{\mathrm{b}}$ & $\mathbf{N A}^{\mathrm{b}}$ \\
\hline & 1b: Adenoma & & $\mathrm{NA}^{\mathrm{b}}$ & $\mathrm{NA}^{\mathrm{b}}$ & $\mathbf{N A}^{\mathrm{b}}$ & - & $\mathrm{NA}^{\mathrm{b}}$ & $\mathrm{NA}^{\mathrm{b}}$ & $\mathbf{N A}^{\mathrm{b}}$ \\
\hline \multirow[t]{2}{*}{2} & 2a: Adenocarcinoma & 0.6 & 40.7 & 22.3 & 1.8 & - & 144.1 & 79.0 & 1.8 \\
\hline & 2b: Adenocarcinoma & & $\mathrm{NA}^{\mathrm{b}}$ & $\mathrm{NA}^{\mathrm{b}}$ & $\mathbf{N A}^{\mathrm{b}}$ & - & $\mathrm{NA}^{\mathrm{b}}$ & $\mathrm{NA}^{\mathrm{b}}$ & $\mathbf{N A}^{\mathrm{b}}$ \\
\hline \multirow[t]{2}{*}{4} & 4a: Adenocarcinoma & 1.8 & 141.9 & 82.6 & 1.7 & + & 51.8 & 11.6 & 4.5 \\
\hline & 4b: Adenoma & & 172.8 & 107.1 & 1.6 & + & 102.6 & 30.6 & 3.4 \\
\hline \multirow[t]{2}{*}{5} & 5a: Leiomyosarcoma & 1.8 & 49.2 & 24.4 & 2.0 & - & $\mathrm{NA}^{\mathrm{c}}$ & $\mathrm{NA}^{\mathrm{c}}$ & $\mathbf{N A}^{\mathbf{c}}$ \\
\hline & 5b: Adenoma & & 115.9 & 36.7 & 3.2 & + & 100.9 & 52.5 & 1.9 \\
\hline 6 & Mast cell tumor & 1.8 & 79.7 & 15.6 & 5.1 & + & 74.8 & 9.2 & 8.1 \\
\hline 7 & Mast cell tumor & 1.8 & 35.4 & 6.3 & 5.6 & + & 51.3 & 25.9 & 2.0 \\
\hline 8 & Mast cell tumor & 1.8 & 63.3 & 63.6 & 1.0 & - & 74.2 & 6.1 & 12.2 \\
\hline 9 & Mast cell tumor & 1.8 & 24.4 & 11.1 & 2.2 & + & 57.0 & 26.2 & 2.2 \\
\hline 10 & Mast cell tumor & 1.8 & 60.5 & 63.3 & 1.0 & - & $\mathrm{NA}^{\mathrm{d}}$ & $\mathrm{NA}^{\mathrm{d}}$ & $\mathbf{N A}^{\mathrm{d}}$ \\
\hline 11 & Mast cell tumor & 1.8 & 39.1 & 33.2 & 1.2 & + & 39.6 & 15.7 & 2.5 \\
\hline 12 & Adenoma & 3.0 & 75.2 & 19.4 & 3.9 & - & 148.5 & 91.7 & 1.6 \\
\hline \multirow[t]{2}{*}{13} & $\begin{array}{l}\text { 13a: SCC / } \\
\text { Adenocarcinoma }\end{array}$ & 3.0 & 28.9 & 20.7 & 1.4 & - & 50.0 & 11.4 & 4.4 \\
\hline & 13b: Adenoma & & $\mathrm{NA}^{\mathrm{d}}$ & $\mathrm{NA}^{\mathrm{d}}$ & $\mathbf{N A}^{\mathrm{d}}$ & - & $\mathrm{NA}^{\mathrm{d}}$ & $\mathrm{NA}^{\mathrm{d}}$ & $\mathbf{N A}^{\mathrm{d}}$ \\
\hline 14 & Soft tissue sarcoma & 1.8 & 130.5 & 31.4 & 4.2 & + & 121.9 & 22.6 & 5.4 \\
\hline 15 & Osteosarcoma & 1.8 & 96.4 & 22.7 & 4.3 & + & 51.7 & 43.2 & 1.2 \\
\hline 16 & Melanoma & 1.8 & 13.0 & 78.8 & 0.2 & - & 1.1 & 19.8 & 0.1 \\
\hline 17 & Adenocarcinoma & 1.8 & 99.8 & 31.4 & 3.2 & + & 142.8 & 9.9 & 14.4 \\
\hline 18 & Lipoma & 1.8 & 61.7 & 14.4 & 4.3 & + & 78.5 & 27.9 & 2.8 \\
\hline \multirow[t]{2}{*}{$19^{\mathrm{e}}$} & 19a: Adenocarcinoma & 1.8 & 113.0 & 30.2 & 3.7 & + & 166.2 & 26.1 & 6.4 \\
\hline & 19b: Adenoma & & $\mathrm{NA}^{\mathrm{d}}$ & $\mathrm{NA}^{\mathrm{d}}$ & $\mathbf{N A}^{\mathrm{d}}$ & - & $\mathrm{NA}^{\mathrm{d}}$ & $\mathrm{NA}^{\mathrm{d}}$ & $\mathbf{N A}^{\mathrm{d}}$ \\
\hline \multirow[t]{2}{*}{$20^{\mathrm{e}}$} & 20a: Adenocarcinoma & 1.8 & 51.6 & 28.7 & 1.8 & - & 57.6 & 29.1 & 2.0 \\
\hline & 20b: Adenocarcinoma & & $\mathrm{NA}^{\mathrm{d}}$ & $\mathrm{NA}^{\mathrm{d}}$ & $\mathbf{N A}^{\mathbf{d}}$ & + & $\mathrm{NA}^{\mathrm{d}}$ & $\mathrm{NA}^{\mathrm{d}}$ & $\mathbf{N A}^{\mathrm{d}}$ \\
\hline $21^{\mathrm{e}}$ & Adenocarcinoma & 1.8 & 20.6 & 16.6 & 1.2 & - & 61.2 & 18.0 & 3.4 \\
\hline $22^{\mathrm{e}}$ & Mast cell tumor & 1.8 & 38.1 & 15.0 & 2.5 & + & 69.1 & 25.9 & 2.7 \\
\hline $23^{e}$ & Mast cell tumor & 1.8 & 42.9 & 17.0 & 2.5 & - & 38.6 & 10.9 & 3.5 \\
\hline $24^{\mathrm{e}}$ & Mast cell tumor & 1.8 & 74.9 & 57.5 & 1.3 & + & 45.9 & 20.0 & 2.3 \\
\hline
\end{tabular}

Fluorescence intensity is expressed as mean value of the region of interest. ${ }^{a}$ Qualitative evaluation indicates whether differentiation of the tumor was feasible during surgical resection of the tumor. ${ }^{b}$ Measurement of the fluorescent signal was not feasible because the administered dose was too low. ${ }^{c}$ Measurement of the ex vivo fluorescent signal was not feasible because no background region of interest could be selected since the resected specimen completely consisted of vaginal tumor. ${ }^{d}$ Measurement of the fluorescent signal was not performed because the tumor diameter was less than $5 \mathrm{~mm}$. ${ }^{\mathrm{e}} \mathrm{Dogs}$ that received the probe $48 \mathrm{~h}$ prior to surgery. Abbreviations: NA, not available; SCC, squamous cell carcinoma; TBR, tumor-to-background ratio; TMR, tumor-to-margin ratio. 
sarcomas, while the opposite was recorded for mast cell tumors.

Qualitative immunohistochemical analyses performed for integrin $\beta_{3}$ also showed variable expression and heterogeneous localization of the subunit in the tumor tissues (Figure 5B). Mammary gland tumors showed moderate expression in both tumor cells and stroma $(i$. e., blood vessels, fibroblasts, myoepithelial cells), while mast cell tumors showed mainly stromal staining. Variable staining intensity was detected in the examined LNs, with predominant stromal localization. Semi-quantitative evaluation by the intensity scoring $(0 / 3)$ system in the tumoral cells revealed a low-to-moderate integrin $\beta_{3}$ expression in mammary tumors, a negligible expression in mast cell tumors and high expression in sarcomas (Table 5). Quantitative analysis of the total tumor stained area (tumor cells and stroma) revealed a moderate integrin $\beta_{3}$ expression in mammary tumors, a low expression in mast cell tumors and high expression in sarcomas.

Given the low sample size and the high variability in integrin expression levels among the samples, no statistical evaluations were performed.

\section{DISCUSSION}

In this canine trial, preliminary safety and imaging efficacy of the fluorescent probe DA364 were assessed during fluorescence-guided surgery in dogs with spontaneous tumors, in combination with standard-ofcare practice. The contrast agent was well tolerated after IV injection at all doses tested, and the median intraoperative TBR was $>1.8$ for mammary tumors, mast cell tumors and sarcomas with TBRs up to 3.9, 5.6, and 4.3, respectively, reached in individual patients, suggesting overall good tumor delineation properties for DA364. Furthermore, DA364 pinpointed four wound beds that contained residual tumor cells (true positives), and 11 fluorescence-positive beds which were tumor-free, confirmed by histopathology (false positives). Overall, the results of the trial suggest that fluorescence-guided surgery using DA364 is safe and feasible, the contrast agent accumulates in different tumor types, and may help to detect residual disease in the wound bed. However, the exploratory nature of the trial and the different variables and protocols tested mandate to consider such results as preliminary; further investigations will be necessary to fully gauge the performance of DA364, particularly its diagnostic accuracy.

The TBRs varied greatly between and within tumor types, as also observed in recent veterinary trials assessing another integrin-targeting probe $[24,25]$. Interestingly, the melanoma showed the lowest TBR, probably because the dark pigmented lesion strongly absorbed the excitation light. Qualitative intra-operative fluorescence examination revealed sharp tumor identification only for half of the lesions. The discrepancy between the semi-quantitative (TBR, post-processing) and the qualitative (subjective visualization, real-time) outcome may be related to several factors. First, qualitative intra-operative discrimination of lesions with a modest TBR (1.1-1.5) may be suboptimal compared to lesions with a higher TBR. Secondly, the hand-held device used in the trial carries an inherent position variability towards the surgical field, and therefore tissue signal intensity and relative contrast may slightly differ between intra-operative examination (e. g., multiple positioning during surgery) and post-processing analyses conducted on a single image. Automatic thresholding algorithms embedded in the imaging system software may facilitate future real-time tumor delineation based on the TBR. The use of fixed-distance intra-operative camera systems with automatic thresholding algorithms may also help to overcome these shortcomings in future trials.
A

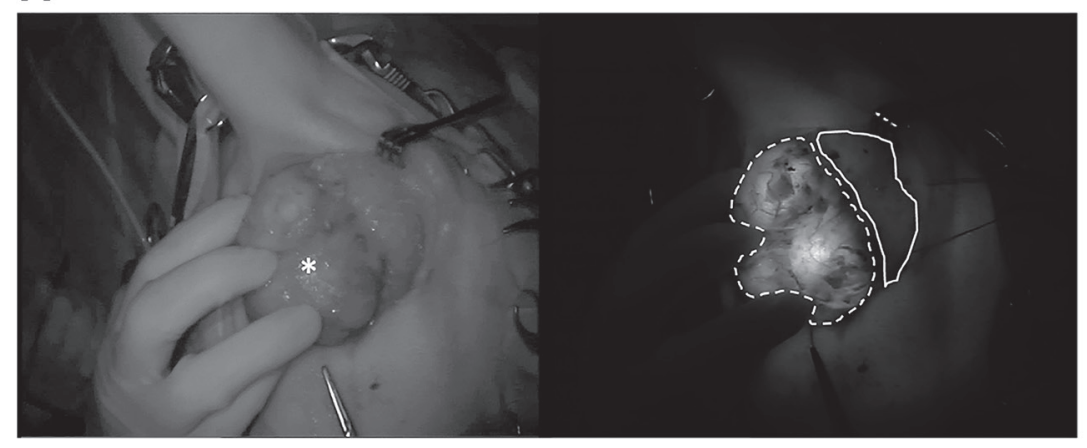

B

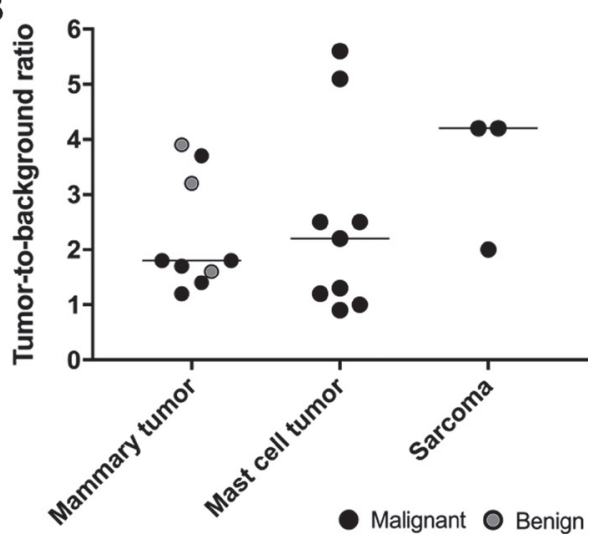

Figure 3: Intra-operative imaging. (A) Representative brightfield (left) and fluorescence (right, $40 \mathrm{~ms}$ exposure) images in situ of an adenocarcinoma $24 \mathrm{~h}$ after administration of DA364 (patient 17;1.8 mg/m²). The asterisk denotes the mass, the dotted line denotes the tumor region of interest and the solid line denotes the background region of interest. (B) Evaluation of tumor-to-background ratios in different tumor types. Horizonal bars represent medians. 
Table 3: Intra-operative evaluation of the lesion by standard-of-care inspection and fluorescence in the wound bed

\begin{tabular}{|c|c|c|c|c|c|}
\hline \multirow[b]{2}{*}{ Tumor } & \multicolumn{2}{|c|}{$\begin{array}{c}\text { Lump margin inspection } \\
\text { (standard-of-care) }^{\mathrm{a}}\end{array}$} & \multicolumn{3}{|c|}{ Wound bed assessment (fluorescence imaging) ${ }^{b}$} \\
\hline & Surgeon & Histopathology ${ }^{c}$ & $\begin{array}{c}\text { Fluorescence } \\
\text { in wound bed } \\
\text { (samples) }\end{array}$ & Histopathology $y^{c}$ & Description \\
\hline 1a: Adenoma & Negative & Negative & Negative & - & - \\
\hline 1b: Adenoma & Negative & Negative & Negative & - & - \\
\hline 2a: Adenocarcinoma & Negative & Negative & Negative & - & - \\
\hline 2b: Adenocarcinoma & Negative & Negative & Negative & - & - \\
\hline 4a: Adenocarcinoma & Negative & Negative & Negative & - & - \\
\hline 4b: Adenoma & Negative & Negative & Negative & - & - \\
\hline 5a: Leiomyosarcoma & Negative & Negative & Positive (1) & Negative & Healthy vaginal wall \\
\hline 5b: Adenoma & Negative & Negative & Negative & - & - \\
\hline 6: Mast cell tumor & Negative & Negative & Positive $(1)^{\mathrm{d}}$ & Negative & $\begin{array}{l}\text { Skin with minimal } \\
\text { perivascular } \\
\text { lymphocytic infiltrate }\end{array}$ \\
\hline 7: Mast cell tumor & Negative & Negative & Positive (1) & Negative & $\begin{array}{c}\text { Adipose and } \\
\text { connective tissue }\end{array}$ \\
\hline 8: Mast cell tumor & Negative & Negative & Positive (1) & Negative & $\begin{array}{l}\text { Adipose tissue and } \\
\text { skeletal muscle }\end{array}$ \\
\hline 9: Mast cell tumor & Negative & Negative & Negative & - & - \\
\hline 10: Mast cell tumor & Negative & Positive & Positive & $\mathrm{NA}^{\mathrm{e}}$ & $\mathrm{NA}^{\mathrm{e}}$ \\
\hline 11: Mast cell tumor & Positive & Positive & Positive (1) & Negative & $\begin{array}{c}\text { Adipose and } \\
\text { connective tissue }\end{array}$ \\
\hline 12: Adenoma & Negative & Negative & Positive $^{f}$ & $\mathrm{NA}^{\mathrm{f}}$ & $\mathrm{NA}^{\mathrm{f}}$ \\
\hline $\begin{array}{l}\text { 13a: SCC / } \\
\text { Adenocarcinoma }\end{array}$ & Negative & Negative & Positive (1) & Negative & Mammary gland \\
\hline 13b: Adenoma & Negative & Negative & Positive $^{f}$ & $\mathrm{NA}^{\mathrm{f}}$ & $\mathrm{NA}^{\mathrm{f}}$ \\
\hline 14: Soft tissue sarcoma & Negative & Negative & Positive (2) & $\begin{array}{l}\text { Negative } \\
\text { Negative }\end{array}$ & $\begin{array}{l}\text { Skeletal muscle } \\
\text { Normal tendon }\end{array}$ \\
\hline 15: Osteosarcoma & Negative & Negative & Positive (2) & $\begin{array}{l}\text { Negative } \\
\text { Negative }\end{array}$ & $\begin{array}{l}\text { Collapsed lung lobe } \\
\text { Thickened pleura }\end{array}$ \\
\hline 16: Melanoma & Positive & Positive & Positive (1) & Negative & $\begin{array}{c}\text { Mucinous connective } \\
\text { tissue }\end{array}$ \\
\hline 17: Adenocarcinoma & Negative & Negative & Negative & - & - \\
\hline 18: Lipoma & Negative & Negative & Negative & - & - \\
\hline 19a: Adenocarcinoma & Negative & Negative & Negative & - & - \\
\hline 19b: Adenoma & Negative & Negative & Negative & - & - \\
\hline 20a: Adenocarcinoma & Negative & Negative & Negative & - & - \\
\hline 20b: Adenocarcinoma & Negative & Negative & Negative & - & - \\
\hline 21: Adenocarcinoma & Negative & Negative & Negative & - & - \\
\hline 22: Mast cell tumor & Positive & Positive & Positive & $\mathrm{NA}^{\mathrm{e}}$ & $\mathrm{NA}^{\mathrm{e}}$ \\
\hline 23: Mast cell tumor & Negative & Negative & Positive (1) & Negative & Normal skin \\
\hline 24: Mast cell tumor & Negative & Negative & Positive (1) & Negative & $\begin{array}{c}\text { Subcutis with large } \\
\text { blood vessel }\end{array}$ \\
\hline
\end{tabular}

aPositive by standard-of-care assessment denotes incomplete resections of the lump or suspicion of contamination in the wound bed. ${ }^{b}$ Positive by fluorescence imaging denotes the presence of a fluorescent signal in the resected sample. ${ }^{c}$ Positive by pathology denotes the presence of tumor tissue. ${ }^{\mathrm{d}}$ False positive tissue removed adjacent to neoplastic tissue and not from the wound bed. ${ }^{~ N o}$ additional biopsy could be taken because of the anatomical location. ${ }^{\mathrm{f}}$ No addititonal biopsy was taken because the high homogenous background was attributed to the high dose that these dogs received. Abbreviation: NA, not available. 
Two previous veterinary clinical trials described the use of an integrin-targeting probe containing a cyclodecapeptide scaffold with $4 \mathrm{c}$ (RGDfK) motifs and a fluorescent dye (Angiostamp, Fluoptics, Grenoble, France), during fluorescence-guided surgical resection of tumors in cats and/or dogs using the Fluobeam system $[24,25]$. In the first trial, 12 cats with fibrosarcoma underwent fluorescence-guided surgery [24], whereas in a second study only one cat with mammary gland tumors and three dogs with different tumor types (mammary gland (2) and/or ovarian (2) disseminated tumors) were enrolled [25]. Angiostamp showed good accumulation in the tumors and high intra-operative TBRs. As pointed out by the investigators, the large tumor-free margin routinely taken in fibrosarcoma cases often emitted a moderate fluorescent signal due to peri-tumoral inflammation, potentially hampering distinct delineation of the tumor itself [24]. A direct comparison between canine and feline studies using Angiostamp for NIRF imaging and our trial using DA364 is challenging. Most important confounding factors include the different patient enrolment and tumor characteristics, the different spectral properties and dosing of the contrast agents, and technical variables related to the camera systems [26]. Another relevant parameter that may strongly affect the study outcome, particularly the TBR, is the definition of the ROIs. For the intra-operative images, we selected as "background" a region as close as possible to the primary tumor, either adjacent or even underneath when the tumor was flipped over. It is not clear how the background areas were selected in the Angiostamp studies to derive the TBR, and whether the ratiometric analysis was performed using an image containing both tumor and background ROIs (as in our study), or different images. A standardized method to select ROIs in fluorescence-guided surgery is necessary to perform an unbiased evaluation of the TBR [27]. The results of the Angiostamp studies and the present trial suggest that integrin-targeting approaches using small fluorescent contrast agents are capable to detect tumor lesions during surgical resection and to assist the surgeon beyond standard-of-care.

During the trial, different doses of the contrast agent were evaluated. The dose of $1.8 \mathrm{mg} / \mathrm{m}^{2}(0.05 \mathrm{mg} / \mathrm{kg}$ human estimated dose after allometric scaling) yielded the most optimal TBR for intra-operative detection of tumor lesions. At lower doses $\left(0.06-0.6 \mathrm{mg} / \mathrm{m}^{2}\right)$, the imaging performance of the contrast agent was suboptimal, probably due to low accumulation and low fluorescent signal detected by the camera system used in this trial which is known to underperform at low concentrations [26]. We believe that the use of a fluorescence camera with higher sensitivity may allow reduction of the drug dosage. Two imaging time-points (24 and $48 \mathrm{~h} \mathrm{PI)} \mathrm{were}$ evaluated to assess the relationship between background signal reduction and tumor contrast generation. Delaying the surgery till $48 \mathrm{~h}$ PI did not improve the TBR. After post hoc analysis of the signal decay, the $T_{1 / 2}$ of DA364 retention in the tissues appeared to be $16.5 \mathrm{~h} \mathrm{PI}$. Therefore, future studies should investigate whether a decrease in time interval between injection and imaging would potentially result in improved in situ TBR and ex vivo TMR. Likely, the most appropriate protocol (dose and imaging time-point) will depend on the type of tumor, and future trials will be necessary to define the optimal protocol for a selected indication.

Besides intra-operative tumor identification, detection of residual disease is probably the other main unmet need that fluorescence-guided surgery may address, to reduce cancer recurrences due to positive margins, to prevent additional surgeries, and to improve the quality of life and survival of the patients. Indeed, the detection of residual disease is a primary endpoint for confirmatory human trials in fluorescence-guided
A

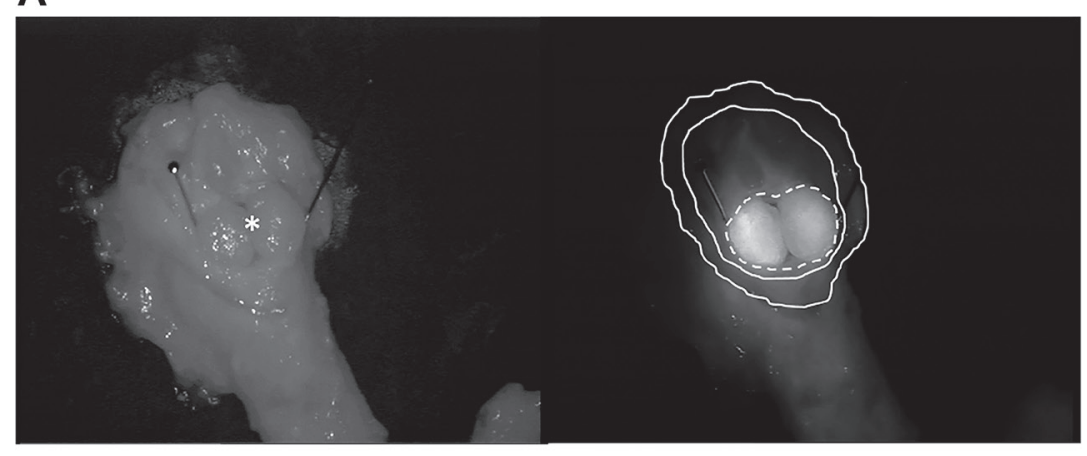

B

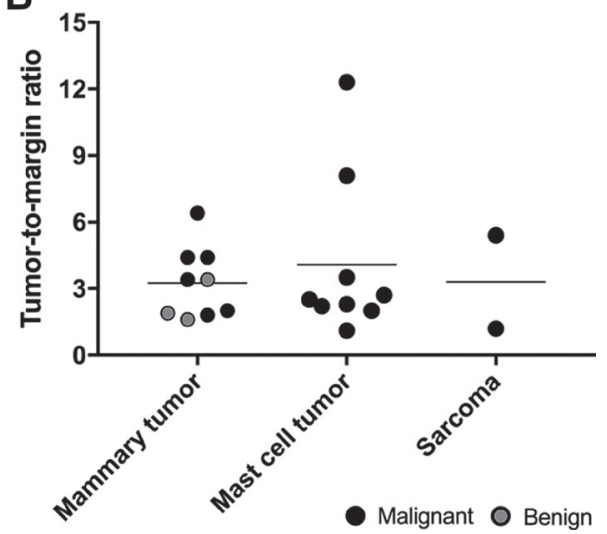

Figure 4: Post-operative imaging. (A) Representative brightfield (left) and fluorescence (right, 40 ms exposure) images of an excised mammary gland adenocarcinoma $48 \mathrm{~h}$ after administration of DA364 (patient $19 ; 1.8 \mathrm{mg} / \mathrm{m}^{2}$ ). The asterisk and the pins denote the mass, the dotted line denotes the tumor region of interest (ROI), the inner solid line the background ROI, and the outer solid line the margin ROI. (B) Evaluation of tumor-to-margin ratios in different tumor types. Horizonal bars represent medians. 
Table 4: Quantitative and qualitative evaluation of fluorescence in excised regional lymph nodes (LN)

\begin{tabular}{llccccc}
\hline Dog & Identification LN & $\begin{array}{c}\text { Fluorescence } \\
\text { LN }\end{array}$ & $\begin{array}{c}\text { Fluorescence } \\
\text { background }\end{array}$ & SBR $^{\mathbf{a}}$ & $\begin{array}{c}\text { Qualitative }_{\text {evaluation }^{\mathbf{b}}} \\
\text { Haistopathology }^{\mathbf{c}}\end{array}$ \\
\hline 1 & Superficial inguinal & 41.8 & 38.5 & $\mathbf{1 . 0 9}$ & - & Negative \\
2 & Superficial inguinal & 12.3 & 4.4 & $\mathbf{2 . 8 0}$ & + & Positive \\
3 & Superficial inguinal & 24.6 & 16.2 & $\mathbf{1 . 5 2}$ & - & Negative \\
4 & Superficial inguinal & 21.6 & 6.0 & $\mathbf{3 . 6 0}$ & + & Positive \\
10 & Axillary & 26.1 & 6.2 & $\mathbf{4 . 2 1}$ & ++ & Positive \\
12 & Superficial inguinal & 59.3 & 39.6 & $\mathbf{1 . 5 0}$ & - & Negative \\
13 & Superficial inguinal & 17.5 & 8.1 & $\mathbf{2 . 1 6}$ & + & Negative \\
14 & Axillary & 12.8 & 8.3 & $\mathbf{1 . 5 4}$ & - & Negative \\
19 & Superficial inguinal & 21.7 & 13.9 & $\mathbf{1 . 5 6}$ & + & Negative \\
21 & Superficial inguinal & 7.2 & 4.2 & $\mathbf{1 . 7 1}$ & - & Negative \\
22 & Popliteal & 30.5 & 8.2 & $\mathbf{3 . 7 2}$ & + & Positive \\
24 & Popliteal & 36.7 & 17.6 & $\mathbf{2 . 0 9}$ & + & Positive \\
\hline
\end{tabular}

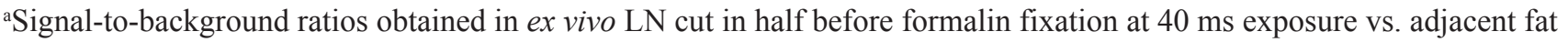
tissue (background). ${ }^{b} Q$ ualitative evaluation denotes whether detection of a fluorescent signal was feasible in the LNs $e x$ vivo before fixation. ${ }^{~}$ Histopathological analysis confirmed the presence (positive) or absence (negative) of neoplastic cells in the LN. Abbreviation: SBR, signal-to-background ratio.

surgery (e. g., NCT03180307 for ovarian cancer, NCT03686215 for breast cancer). NIRF imaging using DA364 highlighted four wound beds containing residual tumor lesions. Particularly in one dog in this trial, the surgeon considered the wound bed to be clean based on standard-of-care inspection, but fluorescence was noted in the caudal wound bed and histopathology confirmed positive margins. In this case, the use of DA364 may have prevented the dog a second surgery. The four true positive wound beds detected in this canine trial suggest positive performance of DA364 for residual disease identification during surgery. On the other hand, 11 wound beds emitting false positive fluorescence were detected, probably due to non-specific accumulation of DA364 in connective and lipid tissues, or binding of the fluorescent probe to the activated endothelial cells, present in the tumor and peri-tumoral environment [19]. In those dogs, additional biopsies were taken. Although no complications were associated with these additional resections, longer anaesthesia and surgery times were recorded. Of note, the vast majority of false positives tissues were removed in mast cell tumor and sarcoma cases, while only one false positive sample was obtained after mastectomy (in a dog receiving the highest tested dose). The rate of false and true
A

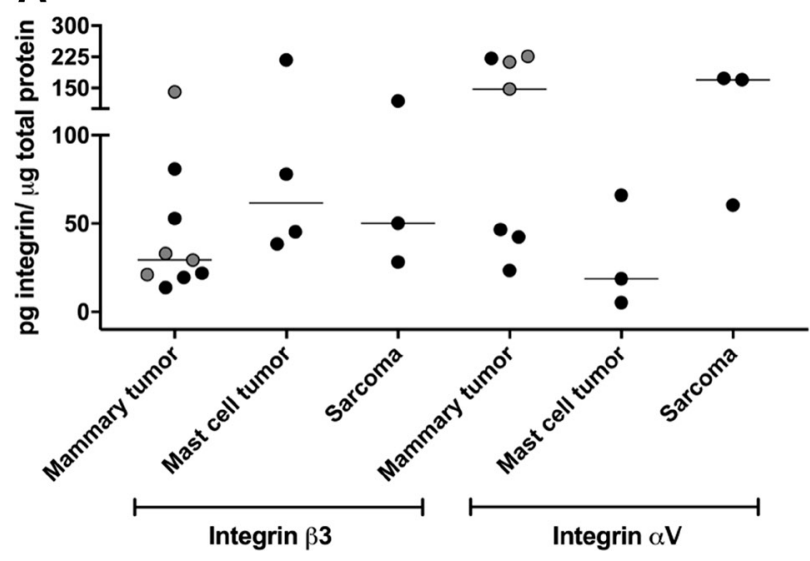

B

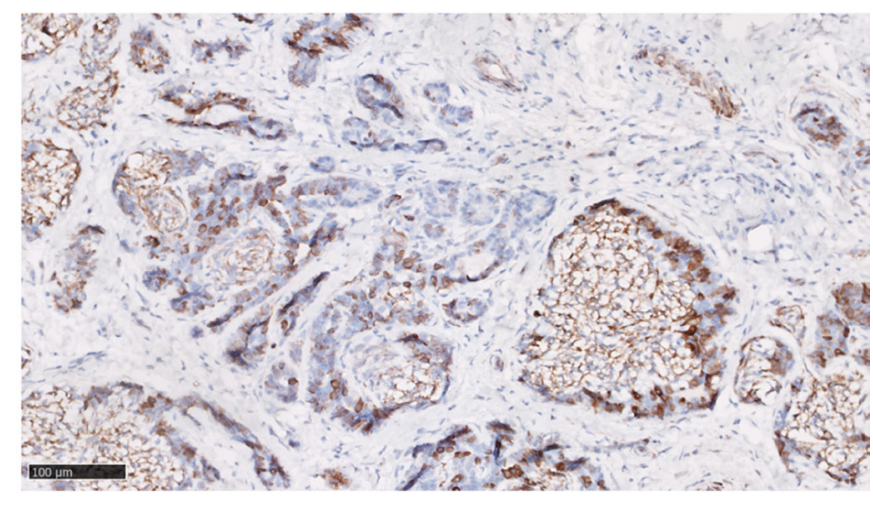

Figure 5: Ex vivo evaluation of integrins expression. (A) Western blot analysis of integrin receptor subunits expression per tumor type. Black circles, malignant tumors; grey circles, benign tumors. Horizonal bars represent medians. (B) Representative image of $\beta_{3}$ integrin immunostaining on a mammary gland adenocarcinoma showing tumor cell and stromal staining (brown, $\beta_{3}$ integrin positive stain; cell nuclei are stained with Hematoxylin in blue). Scale bar, 100 microns. 
Table 5: Semi-quantitative (score) and quantitative (area) evaluation of anti-b ${ }_{3}$ integrin staining in tumor samples

\begin{tabular}{lccc}
\hline $\mathbf{D o g}$ & Tumor type & $\begin{array}{c}\text { IHC }\left(\mathbf{b}_{\mathbf{3}} \text { integrin in tumor cells, }\right. \\
\text { score } \mathbf{0} / \mathbf{3})\end{array}$ & $\begin{array}{c}\text { IHC } \mathbf{( b}_{\mathbf{3}} \text { integrin positive area tumor } \\
\text { area })\end{array}$ \\
\hline $\mathbf{2}$ & 2a: Adenocarcinoma & $1 / 3$ & $25 \%$ \\
& 2b: Adenocarcinoma & $2 / 3$ & $4 \%$ \\
$\mathbf{4}$ & 4a: Adenocarcinoma & - & - \\
& 4b: Adenoma & $0.5 / 3$ & $3 \%$ \\
$\mathbf{5}$ & 5a: Leiomyosarcoma & $3 / 3$ & $53 \%$ \\
& 5b: Adenoma & $1 / 3$ & $13 \%$ \\
$\mathbf{6}$ & Mast cell tumor & $0 / 3$ & $1 \%$ \\
$\mathbf{7}$ & Mast cell tumor & $0 / 3$ & $1 \%$ \\
$\mathbf{8}$ & Mast cell tumor & $0 / 3$ & $1 \%$ \\
$\mathbf{9}$ & Mast cell tumor & $0 / 3$ & $2 \%$ \\
$\mathbf{1 1}$ & Mast cell tumor & $0 / 3$ & $2 \%$ \\
$\mathbf{1 3}$ & 13a: Adenocarcinoma & $0.5 / 3$ & $13 \%$ \\
$\mathbf{1 4}$ & Soft tissue sarcoma & $2 / 3$ & $13 \%$ \\
$\mathbf{1 5}$ & Osteosarcoma & $3 / 3$ & $48 \%$ \\
$\mathbf{1 6}$ & Melanoma & $1 / 3$ & - \\
$\mathbf{1 7}$ & Adenocarcinoma & $0.5-1 / 3$ & $11 \%$ \\
$\mathbf{1 8}$ & Lipoma & $0 / 3$ & $1 \%$ \\
$\mathbf{1 9}$ & 19a: Adenocarcinoma & $2 / 3$ & $16 \%$ \\
$\mathbf{2 0}$ & 19b: Adenoma & $1 / 3$ & $12 \%$ \\
$\mathbf{2 1}$ & 20a: Adenocarcinoma & $0.5 / 3$ & - \\
$\mathbf{2 2}$ & 20b: Adenocarcinoma & - & $-1 \%$ \\
\hline
\end{tabular}

positives is a very important parameter for a diagnostic agent, particularly when considering applications such as breast-conserving surgeries. For this trial, we documented the results case by case, listing all additional tissue samples that were removed after standard-of-care resection. At the same time, we would like to stress that these results should be considered preliminary, given the exploratory nature of the trial and the variety of variables tested (i. e., different doses, different injection-to-imaging time-points, highly heterogeneous patient population and tumor characteristics). Further trials using DA364 will be necessary to assess the diagnostic accuracy of the agent in an optimal protocol and applied to a selected indication, using a fluorescence camera with high performance.

Fluorescence evaluation of resected specimen showed higher fluorescence signal in the center of lesions compared to the safety margin left by the surgeon, confirming the accumulation of DA364 in the lesion detected intra-operatively. Ex vivo ratiometric evaluation of the fluorescence in resected specimens revealed overall higher TMRs than intra-operative TBRs. This is probably because for ex vivo imaging, the specimen was cut in half before imaging, exposing deep fluorescent portions of the sample that may have been masked in vivo by overlying layers of tissue, and not readily detected by the NIRF camera which has limited penetration depth capabilities.

NIRF imaging using DA364 also showed preliminary efficacy for detection of metastasis in a small number of regional LNs. Intra-operative detection of a fluorescent LN might provide crucial additional information during surgery [28]. In this trial, the SBR of resected metastatic LNs was significantly higher than the SBR of non-metastatic LNs. However, in situ evaluation of LN fluorescence was challenging, probably due to the anatomical location (embedded in fat) of the nodes and the limited penetration depth of the technology [7]. Further evaluations will be necessary to confirm these preliminary findings on a larger population.

The presence of the integrin receptors was evaluated on resected specimen. Immunohistochemical evaluation of anti- $\beta_{3}$ showed positive staining in sarcoma and mammary tumor cells, but not in mast tumor cells. 
Presence of the $\beta_{3}$ receptor subunit was found in greater but variable extent in the tumor stroma, suggesting the presence of neoangiogenesis or integrin-expressing tumor-associated cells. In mast cell tumors, the expression of $\beta_{3}$ is likely associated with the presence of tumor vascularization, since no staining was found in tumor cells. Western blot analyses conducted on punch biopsies revealed the presence of $\beta_{3}$ protein in all tumor types, with heterogeneous expression. $\beta_{3}$ protein is a reliable indicator of the $\alpha_{v} \beta_{3}$ integrin receptor, since it only forms dimers with the $\alpha_{\mathrm{v}}$ subunit on tumor epithelial and stromal cells (of note, $\alpha_{\mathrm{IIb}} \beta_{3}$ is only found on platelets), while $\mathrm{a}_{\mathrm{v}}$ protein may also assemble with other $\beta$ subunits. No apparent correlation was found between the presence of $\beta_{3}$ integrin and DA364 signal in tumors. This is probably due to several factors, including the small amount of tissue submitted for target expression analyses (i.e., punch biopsy and thin histological slice) which may not be representative for the whole tumor, but also the contribution of different mechanisms to the tumor accumulation properties of the contrast agent, such as passive diffusion through leaky vessels in addition to target-depended uptake. Furthermore, since the RGDbinding moiety can recognize different integrin receptor dimers other than $\alpha_{\mathrm{v}} \beta_{3}$, an evaluation conducted only on the $\beta_{3}$ protein may be misleading and limitative to address the presence of the biomarkers pool potentially recognized by the molecular imaging agent. Here, we evaluated the expression of the $\alpha_{\mathrm{V}}$ subunit by western blot as surrogate for the $\alpha_{\mathrm{V}}$ integrin receptors pool. Similar to the variable presence of integrin subunit $\beta_{3}$, a heterogeneous expression of the integrin $\alpha_{\mathrm{v}}$ subunit was found in all tumor types. Nonetheless, we acknowledge that assessing the expression of the $\beta_{3}$ and $\alpha_{\mathrm{V}}$ subunits may be suboptimal, affected by the presence of cytoplasmic fractions not relevant for membrane targeted uptake, and not entirely representative of the final heterodimers population. Unfortunately, in this study the evaluation of the intact dimers was not possible by western blot because of the separation in monomers during tissue processing, and the lack of monoclonal antibodies for immunohistochemistry validated on canine tissue. This should not be a limiting factor for human translation since $\alpha_{\mathrm{v}} \beta_{3}, \alpha_{\mathrm{v}} \beta_{5}$ and $\alpha_{\mathrm{v}} \beta_{6}$ antibodies are available and validated for formalin-fixed paraffin-embedded human tissues [29].

We acknowledge some limitations of this study. First, a heterogenous patient population was enrolled with a relatively small number of cases within each tumor type. In veterinary medicine, it is common to pre-operatively assess the nature of the tumor, based on fine-needle-aspirates only. Cytology minimizes the cost for the owner and avoids anaesthesia, required for preoperative core biopsies, but is less accurate than histology. Consequently, post-operative histopathology might identify another tumor type than expected based on preoperative cytology, which was the case for some tumors enrolled in this trial. Second, the hand-held system used in the trial suffers from inherent positioning variability, field inhomogeneity and limited sensitivity. Some samples were not evaluated because of suboptimal image quality. Image quality would benefit from using a fixed-position camera with high sensitivity. Furthermore, the majority of tumors for which evaluation of the signal was not feasible were additional tumors that were diagnosed during physical examination and that had a small diameter (less than 5 $\mathrm{mm}$ ). Measurement of the fluorescence in those samples appeared not feasible. Finally, no parallel control group (e. g., standard-of-care without fluorescence imaging) was included. A control arm may allow randomization and masking, with both arms receiving the contrast agent (to assess safety) and standard-of-care surgery, but only one cohort of patients submitted to fluorescence-guided surgery. This study design may allow to truly assess the added value of fluorescence-guided surgery by evaluating the number of fluorescent residual lesions identified in the wound bed, and the long-term effect on patient quality of life and survival.

\section{MATERIALS AND METHODS}

\section{Contrast agent}

The fluorescent contrast agent DA364 (Bracco Imaging SpA, Italy) was synthetized as previously reported [21]. The empirical formula of DA364 is C63H77N11O20S4 and the molecular mass is $1436.60 \mathrm{~g} /$ mol. DA364 has excitation/emission maxima at 676/696 $\mathrm{nm}$ and very high brightness (molar extinction coefficient: $\left.275,000 \mathrm{~L}^{*} \mathrm{~mol}^{-1}{ }^{*} \mathrm{~cm}^{-1}\right)$ in phosphate buffer saline $(\mathrm{pH}$ 7.4) (unpublished data).

\section{In vitro analyses}

Receptor binding assay and cell uptake blocking experiments were performed as previously described [21]. A 96-well microtiter plate was coated overnight at $4^{\circ} \mathrm{C}$ with $1 \mu \mathrm{g} / \mathrm{mL}$ recombinant human $\alpha_{\mathrm{v}} \beta_{3}$ integrin (Merck-Millipore, Darmstadt, Germany) in coating buffer (20 mM Tris $\mathrm{HCl} \mathrm{pH} 7.4 ; 150 \mathrm{mM} \mathrm{NaCl} ; 1 \mathrm{mM} \mathrm{MnCl}_{2}$; $0.5 \mathrm{mM} \mathrm{MgCl}_{2} ; 2 \mathrm{mM} \mathrm{CaCl}_{2}$ ). After coating, the plate was rinsed in washing buffer, then incubated in blocking buffer ( $3 \% \mathrm{BSA}$ in coating buffer) for $2 \mathrm{~h}$, under shaking and at room temperature (RT). The plate was then rinsed in washing buffer and incubated with the testing compounds in the presence of $1 \mu \mathrm{g} / \mathrm{mL}$ biotinylated vitronectin (Molecular Innovation), for $3 \mathrm{~h}$ at RT. The plate was then rinsed again and incubated in streptavidin-HorseRadish Peroxidase solution (GE Healthcare, Chicago, USA) for $1 \mathrm{~h}$ at RT. After rinsing, the plate was incubated in TetraMethylBenzidine (Sigma-Aldrich, Darmstadt, Germany) solution for $5 \mathrm{~min}$ and the colorimetric reaction was stopped by adding $2 \mathrm{M}$ sulfuric acid. The 
evaluation of the half-maximal inhibitory concentration $\left(\mathrm{IC}_{50}\right)$ for the testing compounds was calculated by measuring the competitor (biotinylated vitronectin) by reading the absorbance at $450 \mathrm{~nm}$ (Optical Density). All samples were analyzed in triplicate and each assay was performed 3 times. $\mathrm{IC}_{50}$-values were determined by nonlinear regression analysis of the slope. For cell uptake experiments, WM266 human melanoma cells were seeded on 24-wells plate over $24 \mathrm{~h}$, and then incubated with $1 \mu \mathrm{M}$ of DA364 in fresh serum-free medium in presence or absence of unconjugated cRGD peptidomimetic $(1,5,10,50,100 \mu \mathrm{M})$ for $20 \mathrm{~min}$ at $37^{\circ} \mathrm{C}$. At the end of incubations, the cells were rinsed with cold PBS, collected and suspended in PBS. Cells were gated according to their light-scattering properties to exclude cell debris and cell fluorescence was analyzed (minimum 20000 events/sample) using Accuri C6 flow cytometer (Becton Dickinson, San Jose, USA). Excitation laser was set at $640 \mathrm{~nm}$ and the fluorescence emission was collected with $670 \mathrm{~nm}$ long pass filter. Three independent experiments were performed in triplicates. Results were expressed as percentage of the maximum uptake (i.e., cells incubated with DA364 in absence of unlabeled cRGD).

\section{Patient enrollment}

Twenty-four client-owned dogs with a tentative diagnosis of surgically manageable solid neoplasia based on localization and palpation (mammary gland tumor) or cytology (melanoma, (sub) cutaneous mast cell tumor, (adeno) carcinoma or sarcoma) were considered for enrolment in the trial. The local research ethical committee granted ethical approval for this clinical trial (Institutional Animal Care and Use Committee; EC2015/124). Additionally, this project received approval of the deontological committee of the Federal Public Service Health, Food Chain Safety and Environment for the enrolment of non-purpose-bred dogs. All owners signed an informed consent form. Pre-surgical staging according to the World Health Organization (WHO) guidelines was completed the day of diagnosis; a thorough physical examination, complete routine blood analysis (hematology and biochemistry), urinalysis, thoracic radiographs (3 orthogonal projections), and/or abdominal ultrasound with guided fine-needle aspiration of regional superficial LNs (if applicable) were performed. Dogs were eligible when no distant metastases were detected and when there were no indications for kidney and/or hepatic impairment based on blood and urinalysis and medical imaging.

\section{DA364 administration}

Prior to administration of the contrast agent, heart rate, respiratory rate, and systolic blood pressure were determined. In dogs diagnosed with a mast cell tumor, $0.2 \mathrm{mg} / \mathrm{kg}$ promethazine (Phenergan, Hikma, Hoorn, The
Netherlands) was administered intramuscularly (IM) to prevent potential histamine release. Dogs received either $0.06 \mathrm{mg} / \mathrm{m}^{2}, 0.6 \mathrm{mg} / \mathrm{m}^{2}, 1.8 \mathrm{mg} / \mathrm{m}^{2}$, or $3 \mathrm{mg} / \mathrm{m}^{2}$ as an IV bolus of undiluted DA364 via a cephalic vein (Table 1). The dose of DA364 was calculated based on the Body Surface Area. Before and after the administration of the contrast agent, the catheter was flushed with $2 \mathrm{~mL}$ sodium chloride ( $\mathrm{NaCl} 0.9 \%$, B. Braun Melsungen AF, Germany) to ensure patency, and then a mandarin was inserted until anesthetic induction at the time of surgery.

\section{Fluorescence imaging}

Near-infrared fluorescence imaging was performed using the clinical Fluobeam $700^{\circledR}$ (Fluoptics, Grenoble, France), a commercially available hand-held system which consists of a control unit with a laser source emitting at $680 \mathrm{~nm}$, apart from an optical head with a charge-coupled device camera and white light emitting diodes for the illumination of the field of view, equipped with a longpass emission filter $(>700 \mathrm{~nm})$. The optical head was fixed in a custom-made tripod, ensuring a fixed working distance of $17 \mathrm{~cm}$ to reach a $6-\mathrm{cm}$ spot diameter at the field of view during pre- and postoperative imaging. For intra-operative imaging, the optical head was hand held and a similar working distance was pursued.

\section{Pre-operative imaging}

The probe was administered 24 or $48 \mathrm{~h}$ prior to surgery. Transcutaneous imaging was performed 5, 10, 30 and 60 min PI and then hourly until $6 \mathrm{~h}$ and $24 \mathrm{~h}$ PI in dogs that received the probe $24 \mathrm{~h}$ prior to surgery. Transcutaneous imaging was performed 5, 10, 30, $60 \mathrm{~min}$, $24 \mathrm{~h}$ and $48 \mathrm{~h}$ PI in dogs that received the probe $48 \mathrm{~h}$ prior to surgery. Dogs were hospitalized and vital parameters (heart rate, respiratory rate and systolic blood pressure) were assessed at predetermined intervals to screen for adverse effects until surgery. Acquired images were analyzed using a commercial image analysis tool (ImageJ v1.52). Regions of interest (ROIs) were drawn on tumor tissues based on the location of the mass identified during visual inspection and palpation, and the signal obtained was used to assess the tissue kinetics of the contrast agent.

\section{Intra-operative imaging}

The Fluobeam $700^{\circledR}$ was covered with a dedicated single-use sterile cover. In dogs diagnosed with a mast cell tumor, administration of promethazine was repeated immediately prior to anaesthetic induction. The choice of general anesthesia and analgesia protocols was based on the attending anesthesiologist's preference. Surgical preparation was routinely performed. Surgical approaches were identical to those routinely used in dogs under white light with routine surgical margins and en bloc regional LN resection (if applicable). The surgery was briefly 
interrupted at several occasions to acquire images and videos while the operation and ambient lights were turned down. Images of the surgical field were obtained before the surgical incision and once the tumor was partially detached from the surrounding tissue and folded over so that the deep border could be imaged in situ at the same time as the wound bed. After removal of the tumor, the wound bed was evaluated by NIRF imaging to assess if there was residual fluorescent signal. Remaining fluorescent tissue was removed or, if this fluorescent tissue was outsized or removal deemed delicate, a biopsy was taken; those samples were identified as "fluorescence positive" and processed separately. A small tissue sample of tumor tissue was immediately frozen at $-80^{\circ} \mathrm{C}$ for western blot analysis. When all images and samples were obtained, the surgical wound was closed routinely and the dog was recovered from anesthesia. Images were analyzed using a commercial image analysis tool (ImageJ v1.52) to assess the fluorescent signal in tumor and background tissue. The background tissue was defined as a putative healthy tissue close to the tumor, either the wound bed or an adjacent tissue in case tumor and bed were not in the same image. The fluorescence signal intensity from the tumor and background tissue was obtained by drawing ROIs on the tissue flap during removal, and the ratio was used to calculate the TBR (Figure 3).

\section{Post-operative imaging}

Images of the excised tissue samples were acquired immediately after surgical removal of the tumor. Tumor and surrounding tissue, fluorescence-positive samples of the wound bed, and the LNs (if applicable) were imaged on a black surface. The tumor itself was then cut in half along its longitudinal axis and imaged with the cut planes facing upwards. Regions of interest were drawn on tumor and safety margins on the acquired ex vivo images using a commercial image analysis tool (ImageJ v1.52), and the fluorescent signal obtained was used to calculate the TMR. Regions of interest were also drawn on the resected LNs and adjacent fat tissue to derive the SBR. All samples were then fixed in abundant amounts of $10 \%$ formalin (CellStor Pot, CellPath, Wales, United Kingdom) for $24 \mathrm{~h}$. Subsequently, half the tumor was further divided in slices of 3-5 mm thickness. A slice (tumor and surroundings) with maximal fluorescence was trimmed to fit into a histology cassette (UniSette, Sacramento, US), the most fluorescent side facing down, and re-immersed in a formalin container.

\section{Western blot}

Tissue samples were homogenized by Precellys homogenizer directly in Lysis buffer (50 mM Tris-HCl pH 8; 150 mM NaCl; 1 mM EDTA; 100 mM NaF; 10\% glycerol; $1 \mathrm{mM} \mathrm{MgCl} ; 1 \%$ TritonX-100; Protease Inhibitors), and put in ice for $20 \mathrm{~min}$. Some samples, particularly those difficult to homogenize, were subsequently pulverized using mortar and pestle in presence of liquid nitrogen. The final extract was sonicated for $15 \mathrm{sec}$ and centrifuged at $14000 \mathrm{~g}$ at $4^{\circ} \mathrm{C}$ for $15 \mathrm{~min}$. The protein content of the supernatant was quantified by the bicinchoninic acid assay method: $50 \mu \mathrm{g}$ of the total extract of each sample was loaded in a $10 \%$ polyacrylamide gel and electrophoresis was performed to separate the proteins by their molecular weight in denaturing conditions (20\% Sodium Dodecyl Sulfate). Proteins were then transferred onto a Polyvinylidene difluoride membrane and subsequently blotted with the antibodies anti-integrin subunit $\beta_{3}$ (\#BK13166, Cell Signaling, Leiden, Netherlands) and anti-integrin subunit $\alpha_{\mathrm{v}}$ (\#Ab179475, Abcam, Cambridge, United Kingdom) to evaluate protein expression, and with the antibody antiactin (\#BK4970, Cell Signaling, Leiden, Netherlands), to allow signal normalization on the loaded proteins. Specific signal was visualized as a single or multiple band by an electrochemiluminescence detection method. The images of the blotted membrane were acquired by a ChemiDoc MP Imaging system and the area of the bands relative to the $\beta_{3}$ expression levels were quantified with the software Image Lab v.4.1. The western blot analysis was repeated at least three times for all dog samples.

\section{Histopathology}

All formalin-fixed tissues were further trimmed, placed in cassettes and subjected to standard dehydration procedure followed by embedding in paraffin $\left(60-65^{\circ} \mathrm{C}\right)$. Four $\mu \mathrm{m}$-thick slices were cut from the paraffin blocks by a microtome. A representative slice of each block was routinely stained using hematoxylin and eosin. Histopathological evaluation was executed by a board-certified veterinary pathologist. Fluorescencepositive tissue samples of the wound bed and the LNs (if applicable) were screened for the presence of tumor cells. The guidelines that the board-certified pathologist used to evaluate the tumor margins are based on the published guidelines by Kamstock and colleagues [30]. Samples containing (sub) cutaneous tumours (mast cell tumours) or sarcomas underwent cross-sectioning. In case of mammary gland tumours, each mammary gland was sampled as well as the lateral margins and the regional LNs. (Oral) melanomas also underwent cross-sectioning.

\section{Immunohistochemistry}

Tissue immunostaining was performed using an anti- $\beta_{3}$ integrin antibody (monoclonal rabbit anti-integrin $\beta_{3}$ antibody, clone EPR2417Y, \#ab75872, Abcam, Cambridge, United Kingdom) and, as control, an antiIgG antibody with matching concentration (rabbit IgG isotype control antibodies, \#3900, Cell signaling, Leiden, Netherlands). Serial sections were stained using routine hematoxylin and eosin for morphology reference. The 
expression of $\beta_{3}$ integrin in tumor cells and stromal tissues was assessed via qualitative, semi-quantitative and quantitative evaluations. Qualitative evaluation was done based on the description of the localization of the labelling (tissue, structures, cell types). The expression of $\beta_{3}$ integrin in tumor cells was semi-quantified with a 4 -tiered score (0: rare or none; $1:<30 \%$ of positive tumors cells; $2: 30 \%$ to $65 \%$ of positive tumor cells; 3 : $>65 \%$ of positive tumor cells). This visual evaluation assessed the labelling in the tumor cells only (stroma not included). A quantitative evaluation of the surface with IHC staining in selected tumor areas was achieved using HaloTM software (IndicaLabs, Albuquerque, NM). The selected tumor regions were chosen as large as possible, avoiding areas with artifacts (tissue folds, non-specific staining). The results were expressed as a percentage of stained areas per selected tumor surface. This represented an evaluation of the labelling in the tumor cells and in the stroma.

\section{Statistics}

Normality was confirmed for the in vivo TBR obtained in benign and malignant tumors, and ex vivo STB obtained in removed LNs (Kolmogorov-Smirnov test and Shapiro-Wilk test). Statistical differences between the TBR of malignant versus benign tumors, the TBR of malignant tumors in patients that received the product at $24 \mathrm{~h}$ vs $48 \mathrm{~h}$ prior to surgery, and STBs in normal versus metastatic LNs were evaluated using the independent $t$-test. A $p$-value $<0.05$ was considered significant. Normality was not confirmed for the ex vivo TMR values in benign and malignant tumors nor for the individual tumor types (mammary tumors, mast cell tumors and sarcomas). Statistical differences between the TMR of malignant versus benign tumors were evaluated using the Mann-Whitney $U$ test. A $p$-value of $<0.05$ was considered significant.

\section{CONCLUSIONS}

The integrin-targeting fluorescent probe DA364 did not raise safety concerns and showed accumulation in different types of spontaneous tumors. Fluorescenceguided surgery using DA364 is feasible, and may facilitate the delineation of primary lesions and the identification of residual disease missed by standard-of-care inspection. Larger clinical trials based a uniform patient population, a sensitive imaging system, and a specific dosing and imaging protocol are necessary to allow evaluation of sensitivity and specificity of the novel contrast agent.

\section{Abbreviations}

ICG: Indocyanine Green; IM: intramuscularly; IV: intravenous; LN: lymph node; NIRF: near-infrared fluorescence; PI: post-injection; RGD: Arg-Gly-Asp; ROI: region of interest; RT: room temperature; TBR: tumor-to-background ratio; TMR: tumor-to-margin ratio; SBR: signal-to-background ratio; WHO: world health organization.

\section{Author contributions}

GV, CB, LM, AM, FT and HdR designed the study. SF and HdR, EA, CB, AC, LM, GV, PO, CA, IT, FB performed the experiments and analyzed the data. SF, CB, FB and HdR drafted the manuscript. All authors reviewed the manuscript.

\section{ACKNOWLEDGMENTS}

The authors want to thank the owners of the dogs that participated in this study.

\section{CONFLICTS OF INTEREST}

This manuscript is based on our original research and had neither been published, nor is being considered elsewhere for publication. CB, AC, LM, PO, CA, IT, AM, FT, FB are employees of Bracco Imaging spa. All the other authors declare no commercial or financial conflicts of interest.

\section{FUNDING}

This work was supported by the Research Foundation - Flanders (FWO; grant number 1S 00717N) and by a research grant from Bracco Imaging SpA.

\section{REFERENCES}

1. Rosenthal EL, Warram JM, Bland KI, Zinn KR. The status of contemporary image-guided modalities in oncologic surgery. Ann Surg. 2015; 261:46-55. https://doi. org/10.1097/SLA.0000000000000622. [PubMed]

2. Woolgar JA, Triantafyllou A. A histopathological appraisal of surgical margins in oral and oropharyngeal cancer resection specimens. Oral Oncol. 2005; 41:1034-43. https://doi.org/10.1016/j.oraloncology.2005.06.008. [PubMed]

3. Iczkowski KA, Lucia MS. Frequency of positive surgical margin at prostatectomy and its effect on patient outcome. Prostate Cancer. 2011; 2011:673021. https://doi. org/10.1155/2011/673021. [PubMed]

4. Atkins J, Al Mushawah F, Appleton CM, Cyr AE, Gillanders WE, Aft RL, Eberlein TJ, Gao F, Margenthaler JA. Positive margin rates following breast-conserving surgery for stage I-III breast cancer: palpable versus nonpalpable tumors. J Surg Res. 2012; 177:109-15. https://doi.org/10.1016/j. jss.2012.03.045. [ubMed] 
5. Ravasz LA, Slootweg PJ, Hordijk GJ, Smit F, van der Tweel I. The status of the resection margin as a prognostic factor in the treatment of head and neck carcinoma. J Craniomaxillofac Surg. 1991; 19:314-18. https://doi. org/10.1016/s1010-5182(05)80339-7. [PubMed]

6. Frangioni JV. New technologies for human cancer imaging. J Clin Oncol. 2008; 26:4012-21. https://doi.org/10.1200/ JCO.2007.14.3065. [PubMed]

7. Gioux S, Choi HS, Frangioni JV. Image-guided surgery using invisible near-infrared light: fundamentals of clinical translation. Mol Imaging. 2010; 9:237-55. https://doi. org/10.2310/7290.2010.00034. [PubMed]

8. Nagaya T, Nakamura YA, Choyke PL, Kobayashi H. Fluorescence-guided surgery. Front Oncol. 2017; 7:314. https://doi.org/10.3389/fonc.2017.00314. [PubMed]

9. Tummers QR, Hoogstins CE, Peters AA, de Kroon CD, Trimbos JB, van de Velde CJ, Frangioni JV, Vahrmeijer AL, Gaarenstroom KN. The value of intraoperative near-infrared fluorescence imaging based on enhanced permeability and retention of indocyanine green: feasibility and falsepositives in ovarian cancer. PLoS One. 2015; 10:e0129766. https://doi.org/10.1371/journal.pone.0129766. [PubMed]

10. Liberale G, Bourgeois P, Larsimont D, Moreau M, Donckier $\mathrm{V}$, Ishizawa $\mathrm{T}$. Indocyanine green fluorescence-guided surgery after IV injection in metastatic colorectal cancer: a systematic review. Eur J Surg Oncol. 2017; 43:1656-67. https://doi.org/10.1016/j.ejso.2017.04.015. [PubMed]

11. Holt D, Okusanya O, Judy R, Venegas O, Jiang J, DeJesus E, Eruslanov E, Quatromoni J, Bhojnagarwala P, Deshpande C, Albelda S, Nie S, Singhal S. Intraoperative near-infrared imaging can distinguish cancer from normal tissue but not inflammation. PLoS One. 2014; 9:e103342. https://doi. org/10.1371/journal.pone.0103342. [PubMed]

12. Harlaar NJ, Koller M, de Jongh SJ, van Leeuwen BL, Hemmer PH, Kruijff S, van Ginkel RJ, Been LB, de Jong JS, Kats-Ugurlu G, Linssen MD, Jorritsma-Smit A, van Oosten $\mathrm{M}$, et al. Molecular fluorescence-guided surgery of peritoneal carcinomatosis of colorectal origin: a single-centre feasibility study. Lancet Gastroenterol Hepatol. 2016; 1:283-90. https:// doi.org/10.1016/S2468-1253(16)30082-6. [PubMed]

13. Hoogstins CE, Boogerd LS, Sibinga Mulder BG, Mieog JS, Swijnenburg RJ, van de Velde CJ, Farina Sarasqueta A, Bonsing BA, Framery B, Pèlegrin A, Gutowski M, Cailler F, Burggraaf J, Vahrmeijer AL. Image-guided surgery in patients with pancreatic cancer: first results of a clinical trial using SGM-101, a novel carcinoembryonic antigentargeting, near-infrared fluorescent agent. Ann Surg Oncol. 2018; 25:3350-57. https://doi.org/10.1245/s10434-0186655-7. [PubMed]

14. Gutowski M, Framery B, Boonstra MC, Garambois V, Quenet F, Dumas K, Scherninski F, Cailler F, Vahrmeijer AL, Pèlegrin A. SGM-101: an innovative near-infrared dye-antibody conjugate that targets CEA for fluorescenceguided surgery. Surg Oncol. 2017; 26:153-62. https://doi. org/10.1016/j.suronc.2017.03.002. [PubMed]
15. Keating JJ, Runge JJ, Singhal S, Nims S, Venegas O, Durham AC, Swain G, Nie S, Low PS, Holt DE. Intraoperative near-infrared fluorescence imaging targeting folate receptors identifies lung cancer in a large-animal model. Cancer. 2017; 123:1051-60. https://doi.org/10.1002/ cncr.30419. [PubMed]

16. van Dam GM, Themelis G, Crane LM, Harlaar NJ, Pleijhuis RG, Kelder W, Sarantopoulos A, de Jong JS, Arts HJ, van der Zee AG, Bart J, Low PS, Ntziachristos V. Intraoperative tumor-specific fluorescence imaging in ovarian cancer by folate receptor- $\alpha$ targeting: first in-human results. Nat Med. 2011; 17:1315-19. https://doi.org/10.1038/nm.2472. [PubMed]

17. Hyun H, Henary M, Gao T, Narayana L, Owens EA, Lee JH, Park G, Wada H, Ashitate Y, Frangioni JV, Choi HS. 700-nm zwitterionic near-infrared fluorophores for dualchannel image-guided surgery. Mol Imaging Biol. 2016; 18:52-61. https://doi.org/10.1007/s11307-015-0870-4. [PubMed]

18. Choi HS, Nasr K, Alyabyev S, Feith D, Lee JH, Kim SH, Ashitate Y, Hyun H, Patonay G, Strekowski L, Henary M, Frangioni JV. Synthesis and in vivo fate of zwitterionic near-infrared fluorophores. Angew Chem Int Ed Engl. 2011; 50:6258-63. https://doi.org/10.1002/anie.201102459. [PubMed]

19. Desgrosellier JS, Cheresh DA. Integrins in cancer: biological implications and therapeutic opportunities. Nat Rev Cancer. 2010; 10:9-22. https://doi.org/10.1038/ nrc2748. [PubMed]

20. Hamidi H, Ivaska J. Every step of the way: integrins in cancer progression and metastasis. Nat Rev Cancer. 2018; 18:533-48. https://doi.org/10.1038/s41568-018-0038-Z. [PubMed]

21. Lanzardo S, Conti L, Brioschi C, Bartolomeo MP, Arosio D, Belvisi L, Manzoni L, Maiocchi A, Maisano F, Forni G. A new optical imaging probe targeting $\alpha \mathrm{V} \beta 3$ integrin in glioblastoma xenografts. Contrast Media Mol Imaging. 2011; 6:449-58. $\quad$ https://doi.org/10.1002/cmmi.444. [PubMed]

22. Conti L, Lanzardo S, Iezzi M, Montone M, Bolli E, Brioschi C, Maiocchi A, Forni G, Cavallo F. Optical imaging detection of microscopic mammary cancer in ErbB-2 transgenic mice through the DA364 probe binding $\alpha \mathrm{v} \beta 3$ integrins. Contrast Media Mol Imaging. 2013; 8:350-60. https://doi.org/10.1002/cmmi.1529. [PubMed]

23. Capasso D, de Paola I, Liguoro A, Del Gatto A, Di Gaetano S, Guarnieri D, Saviano M, Zaccaro L. RGDechi-hCit: $\alpha v \beta 3$ selective pro-apoptotic peptide as potential carrier for drug delivery into melanoma metastatic cells. PLoS One. 2014; 9:e106441. https://doi.org/10.1371/journal.pone.0106441. [PubMed]

24. Wenk CH, Ponce F, Guillermet S, Tenaud C, Boturyn D, Dumy P, Watrelot-Virieux D, Carozzo C, Josserand V, Coll JL. Near-infrared optical guided surgery of highly infiltrative fibrosarcomas in cats using an anti- $\alpha v \beta 3$ integrin 
molecular probe. Cancer Lett. 2013; 334:188-95. https:// doi.org/10.1016/j.canlet.2012.10.041. [PubMed]

25. Mery E, Golzio M, Guillermet S, Lanore D, Le Naour A, Thibault B, Tilkin-Mariamé AF, Bellard E, Delord JP, Querleu D, Ferron G, Couderc B. Fluorescence-guided surgery for cancer patients: a proof of concept study on human xenografts in mice and spontaneous tumors in pets. Oncotarget. 2017; 8:109559-74. https://doi.org/10.18632/ oncotarget.22728. [PubMed]

26. DSouza AV, Lin H, Henderson ER, Samkoe KS, Pogue BW. Review of fluorescence guided surgery systems: identification of key performance capabilities beyond indocyanine green imaging. J Biomed Opt. 2016; $21: 80901$. https://doi.org/10.1117/1.JBO.21.8.080901. [PubMed]

27. Hoogstins C, Burggraaf JJ, Koller M, Handgraaf $H$, Boogerd L, van Dam G, Vahrmeijer A, Burggraaf J. Setting standards for reporting and quantification in fluorescenceguided surgery. Mol Imaging Biol. 2019; 21:11-18. https:// doi.org/10.1007/s11307-018-1220-0. [PubMed]

28. Ran S, Volk L, Hall K, Flister MJ. Lymphangiogenesis and lymphatic metastasis in breast cancer. Pathophysiology.
2010; 17:229-51. https://doi.org/10.1016/j.pathophys.2009. 11.003. [PubMed]

29. Vogetseder A, Thies S, Ingold B, Roth P, Weller M, Schraml $\mathrm{P}$, Goodman SL, Moch H. Av-integrin isoform expression in primary human tumors and brain metastases. Int J Cancer. 2013; 133:2362-71. https://doi.org/10.1002/ijc.28267. [PubMed]

30. Kamstock DA, Ehrhart EJ, Getzy DM, Bacon NJ, Rassnick KM, Moroff SD, Liu SM, Straw RC, McKnight CA, Amorim RL, Bienzle D, Cassali GD, Cullen JM, et al, and American College of Veterinary Pathologists' Oncology Committee. Recommended guidelines for submission, trimming, margin evaluation, and reporting of tumor biopsy specimens in veterinary surgical pathology. Vet Pathol. 2011; 48:19-31. https://doi. org/10.1177/0300985810389316. [PubMed]

31. LaFlamme DP. Development and validation of a body condition score system for dogs. Canine Pract. 1997; 22:10-15.

32. Owen LN. TNM Classification of tumors in domestic animals. Geneva: World Health Organisation; 1980. 